\title{
Stimulated Raman scattering of Rhodamine 6G in polymer samples enclosed in scattering cover
}

\author{
V.P.Yashchuk, O.O.Komyshan \\ T. Shevchenko National University of Kyiv, \\ 64/13 Volodymyrska St., 01601 Kyiv, Ukraine
}

Received January 20, 2015

\begin{abstract}
Radiation of rhodamine 6G is investigated in the "photon boxes" which are dyed polymeric samples in scattering cover of dielectric microparticles. These samples are multiple scattering media (MSM) in which interaction of the scattering microparticles with dye molecules is reduced considerably as compared to usually used MSM for random lasing (RL) what is important because of surface activity of these particles. In these samples coupled phenomenon of RL and stimulated Raman scattering (SRS) was observed. Features of SRS-RL phenomenon are identical to ones observed in other investigated MSM (vesicular films and suspension of microparticles) what allow applying these samples for obtaining of dye Raman spectra. SRS efficiency in "photon boxes" grows under pump increase and decrease of volume ratio of its internal area and active (excited) region. The results show that "photon boxes" of minimal size are promising for Raman spectra studying using SRS-RL phenomenon.
\end{abstract}

Keywords: stimulated Raman scattering (SRS), random lasing (RL), multiple scattering media, dye.

Исследовано излучение родамина $63 \AA$ в "фотонных ящиках", представляющих собой окрашенные полимерные образцы в рассеивающей оболочке диэлектрических частиц. Эти образцы являются многократно рассеивающими средами (MPC), в которых значительно уменьшено взаимодействие расеивающх микрочастиц с молекулами красителя по сравнению с обычно используемыми MPC для хаотической генерации (ХГ), что важно ввиду поверхностной активности этих частиц. В этих образцах наблюдался сдвоенный эффект ХГ и вынужденного комбинационного рассеяния (ВКР). Особенности явления ВКР-ХГ идентичны наблюдаемым в других исследованных МРC (везикулярных пленках и суспензиях микрочастиц), что позволяет использовать эти образцы для получения спектров комбинационного рассеяния красителей. Эффективность ВКР в "фотонных ящиках" возрастает при увеличении накачки и уменьшении относительного объема их внутренней части к активной (возбужденной) области. Эти результаты демонстрируют перспективность "фотонных ящиков" минимальных размеров для изучения спектров комбинационного рассеяния с помощью явления ВКР-ХГ.

Вимушене комбінаційне розсіяння родаміну 6Ж у полімерних зразках з сильно розсіювальною оболонкою. В.П.Ящук, О.О.Колишан.

Досліджено випромінювання родаміну $6 Ж$ у "фотонних ящиках", які представляють собою забарвлені полімерні зразки у розсіювальній оболонці діелектричних частинок. Ці зразки є багатократно розсіюювальними середовищами (БРС), в яких значно зменшено взаємодію розсіювальних мікрочастинок 3 молекулами барвника у порівнянні з БРС, які зазвичай використовуються для хаотичної генерації (ХГ), що важливо в зв'язку з поверхневою активністю цих частинок. У цих зразках спостерігався здвоєний ефект ХГ і вимушеного комбінаційного розсіяння (ВКР). Особливості явища ВКР-ХГ ідентичні тим, які спостерігаються в інших досліджених БРС (везикулярних плівках і суспензіях мікрочастинок), що дозволяє використовувати ці зразки для отримання спектрів комбінаційного розсіяння барвників. Ефективність ВКР 
в "фотонних ящиках" зростає при збільшенні накачування і зменшенні відносного об'єму їх внутрішньої частини до активної (збудженої) області. Ці результати демонструють, що "фотонні ящики" мінімальних розмірів є перспективними для вивчення спектрів комбінаційного розсіяння за допомогою явища ВКР-ХГ.

\section{Introduction}

In dyed multiple scattering media (MSM) two stimulated emission processes may occur simultaneously: random lasing (RL) [1] and stimulated Raman scattering (SRS) [2,3]. RL is a process of stimulated emission due to multiple elastic scattering of light on specially introduced scattering particles, substituting for multiple reflection of light on cavity mirrors. Because of the absence of resonance conditions, the RL spectrum is continuous. As both processes are simultaneous, RL influences SRS according to CARSlike mechanism.

As it is known, coherent active Raman spectroscopy (CARS) method requires two radiation components for coherent excitation of molecule vibration. Only those vibrations are excited that are in resonance with the frequency difference of these radiations. In dyed MSM, the first component is external pumping radiation, while RL radiation arising in the media plays the role of the second component [4]. Because of continuous RL spectrum, resonant conditions are provided for all molecule vibrations with Stokes frequencies within the range of this spectrum. This important feature of SRS in MSM makes it possible to obtain Raman spectra of dyes from the spectra of their secondary radiation in MSM. This radiation is caused by both effects and consists of two components: continuous (conditioned by RL) and linear (conditioned by SRS). The procedure of obtaining Raman spectra was developed in [5]. An important advantage of the developed method is the absence of unfavorable effects of luminescence illumination, which is a considerable restriction in Raman spectroscopy.

The optimal multiple scattering medium (MSM) for obtaining SRS-RL effect of dyes is dyed vesicular polymer films, which are a specific type of intercalation medium where light diffusively flows in the polymer between gas vesicles. This provides for efficient light scattering because of high relative refraction index of the polymer to gas in vesicles $(n>>1.5)$ [5,6]. However, some dyes are unstable in copolymers (vinylidene chloride, acrylonitrile methyl and methacrylate) used in the film manufacturing. They fade both on stages of the film manufacturing and under illumination by pump radiation.
Rather effective MSM are concentrated suspension of dielectric microparticles of high refractive materials in polymers or solutions. But these particles also lead to certain dye bleaching because of their surface activity.

Due to this problem, obtaining of vibration spectra of dyes from SRS-RL effect in these MSM can be complicated for some dyes. That's why looking for other ways of creation of MSM is important problem.

\section{Experimental}

We have prepared samples in which multiple scattering of light is produced not in the bulk of the dyed sample, but on its boundary (dense layer of microparticles of high refractive material introduced into the polymer). Such samples are MSM where the problems listed above are reduced considerably, because they do not require a special copolymer (being used for fabrication of vesicular film), but allow choosing a polymer that is inert to a specified dye.

In addition interaction of dye molecules with scattering particles in these samples may be minimized because these particles are contained only on the boundary of the sample. It is possible to denominate these MSM "photon boxes" because the cover formed by microparticles provides effective diffuse scattering that holds emitted photons inside the sample.

The internal part of the samples was made of dyed homogeneous (without particles) polymer oligourethane acrylate (OUA), which is inert to almost all dyes. Rhodamine 6G (R6G) was used as a dye whose SRS was well investigated previously in vesicular films $[3,5]$, so these data could be used for comparison with data obtained in this work. The dye concentration was the same as usually used in the vesicular films for SRS observation ( $5 \mathrm{mmol} / \mathrm{l})$. The external part of the samples was fabricated from concentrated suspension of borazon microparticles $(\approx 2 \mu \mathrm{m}$ diameter $)$ in the same (but not dyed) polymer for minimizing the number of dye molecules which might interact with the particles.

The preparation procedure of "photon boxes" consists of two stages. The first stage is fabrication of the internal homogeneous part of the dyed polymer. To do this, 


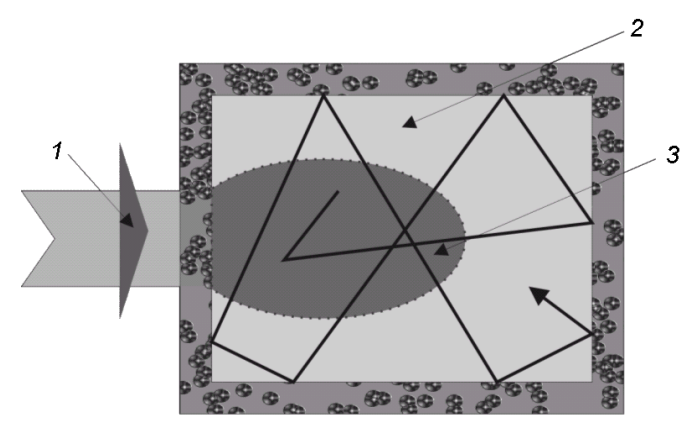

Fig. 1. Scheme of "photon box" pumping through the diffusive cover: $1-$ pump, $2-$ RL localization region $V_{R L}, 3$ - active zone $V_{a c t}$.

the dyed OUA with photo initiator (isobutyl ether benzoin) was poured between two precleaned glass plates to prevent the access of oxygen under photopolymerization. The polymerization was carried out under irradiation of $365 \mathrm{~nm}(\mathrm{Hg}$ lamp), matching with absorbtion spectrum of the photo initiator. The duration of exposure varied depending on the sample thickness, the mercury lamp power and concentration of the dye, being about 3-5 min from each side of the sample.

The second stage is fabrication of scattering cover. A $1.5 \times 1.5 \times 1.5 \mathrm{~mm}^{3}$ piece of the prepared homogeneous dyed polymer was dipped in concentrated suspension of borazon microparticles $(\sim 10 \%$ by weight with respect to polymer) in blank OUA and was covered with strips of polyethylene film to prevent oxygen access; then it was photopolymerized. After polymerization the strips were removed. Such design of the sample minimizes the contact of dye molecules and scattering particles: the latter are located only in the cover, where dye molecules are absent. Interaction between them is possible only in a narrow layer on the boundary surface between the cover and inner dyed part of the sample. So, possible influence of the particles on stability of dye molecules was assumed to be negligible.

"Photon boxes" are pumped by second harmonic of $Q$-switched YAG-Nd ${ }^{3+}$ laser through the cover (Fig. 1) or a special window in it. Both designs are approximately of the same efficiency but the first variant is preferable because its fabrication is easier and the sample may be smaller. The intensity of pump radiation is varied with grey glass filters in the range $0.1 \div 3 \mathrm{MW} / \mathrm{mm}^{2}$. The radiation spectra of $\mathrm{R} 6 \mathrm{G}$ in "photon box" were single-shot registered by spectrograph and CCD camera with spectral resolution $0.3 \mathrm{~nm}$. The presented results were obtained at near helium temperatures $(\approx 5-6 \mathrm{~K})$.

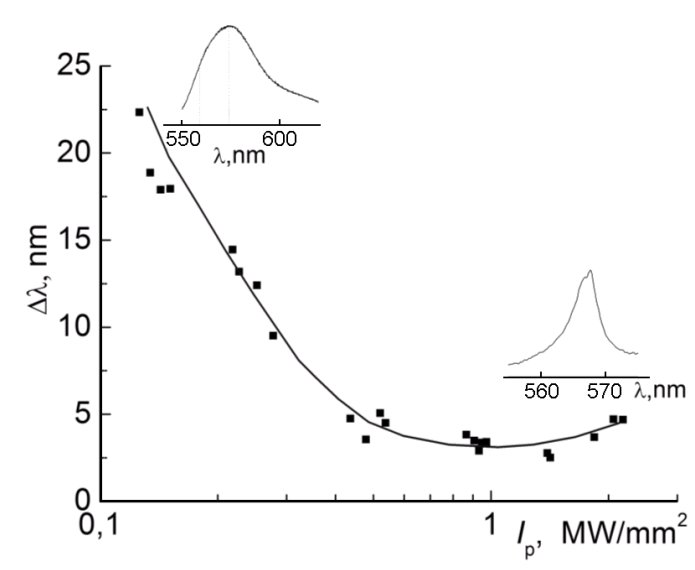

Fig. 2. Dependence of the emission spectrum width of R6G "photon" box on pumping intensity. Inserts show the emission spectra of the sample at pump intensities of 0.15 and $2.5 \mathrm{MW} / \mathrm{mm}^{2}$.

\section{Results and discussion}

Radiation spectra of "photon boxes" were studied as function of the pump intensity and the box size. It has been found that RL and manifestations of SRS depend substantially on the "photon box" size.

The samples may be characterized by the volume ratio of the $\mathrm{RL}$ localization region $V_{R L}$ and active zone $V_{\text {act }}$ (Fig. 1). The RL localization region is a zone where RL radiation can propagate. In the "photon boxes" this region coincides with the inner area of the sample enclosed in the cover. The active region is defined by pump beam and is approximately equal to the cross-section area of laser spot multiplied by the sample thickness. "Photon boxes" of several relative sizes $\gamma=V_{R L} / V_{a c t}$ were tested. In the large "box" $(\gamma \approx 200)$ only luminescence radiation with wide spectrum was observed under any pump intensity. Under decreasing $\gamma$, the tendency of radiation spectrum to narrowing become apparent under high pump intensities. And in the small "box" $\left(\gamma \approx 20, V_{R L}=2.4 \mathrm{~mm}^{3}\right)$ radiation spectrum dependence on pump intensity reveals a distinctive feature of the behavior of the "coupled" SRS-RL phenomenon.

Under pump increase (from 0.1 to $0.5 \mathrm{MW} / \mathrm{mm}^{2}$ ), the radiation spectrum narrows to $5 \mathrm{~nm}$ (Fig. 2), which is typical value for $\mathrm{RL}[3,7]$. The threshold pump intensity of RL in the "photon box" is approximately twice higher than in concentrated suspension of borazon particles [6] and by an order - as compared to vesicular films [2]. But taking into account the tendency of spectrum narrowing with $\gamma$, one may believe that RL threshold lowering in 


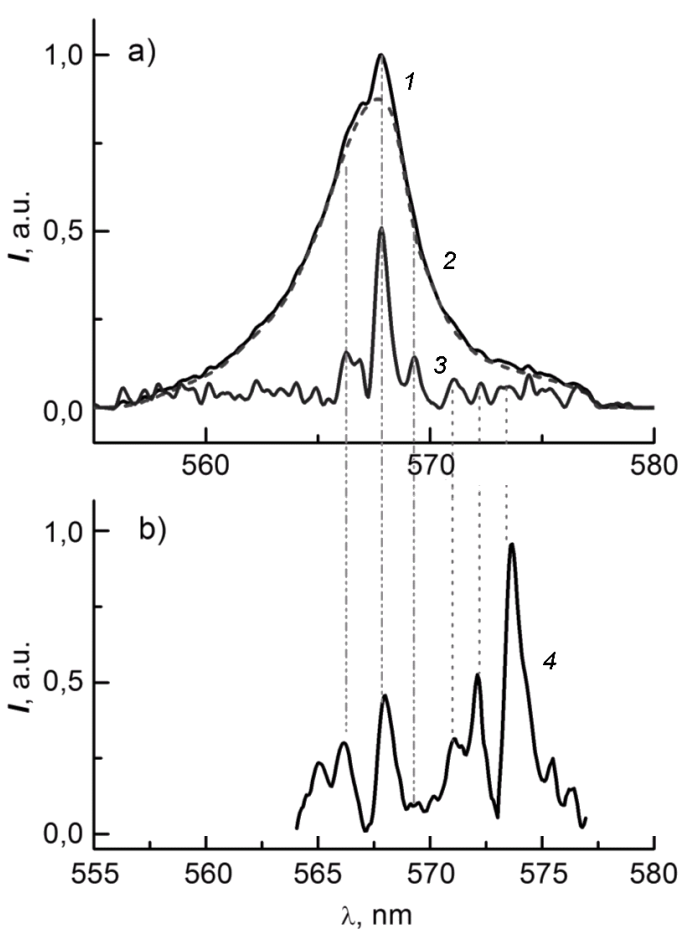

Fig. 3. (a) - The SRS-RL spectrum of R6G "photon box" (1) and its continuous (RL) and linear components (SRS) (2 and 3) under pump intensity $3 \mathrm{MW} / \mathrm{mm}^{2}$. The linear component was amplified by 4 times. (b) - Raman spectrum section of R6G obtained from SRS-RL spectrum of R6G vesicular film (4).

the "photon box" can be achieved under further decrease of it relative size.

Under further increase of pump the radiation spectrum becomes wider and reveals narrow lines of approximately $0.5 \mathrm{~nm}$. The lines are observed in radiation spectra of R6G "photon box" only above RL threshold. Frequencies of these lines match with the frequencies of R6G Stokes lines obtained from SRS-RL phenomena in vesicular films $[3,5]$. This is illustrated by Fig. 3a, which presents SRS-RL spectrum of the "photon box" $(\gamma=20)$ at the pump intensity $3 \mathrm{MW} / \mathrm{mm}^{2}$ and its constituent parts: continuous (conditioned by RL) and linear (conditioned by SRS) spectral components. Even the weakest lines of the spectrum, which appear on noise levels, coincide with the Raman lines of R6G and therefore they cannot be considered as noise (Fig. 3b). The comparison allows us to conclude that SRS lines are manifested in the emission spectra of the "photon boxes". When the relative volume of the sample increases, SRS lines disappear because of worse conditions for stimulated emission in the sample due to reabsorption of radiation luminescence. SRS-RL phenomena in the "photon boxes" are very sensitive to radiation reabsorption of luminescence dye, which is revealed in their strong dependence on the experimental conditions and dye.

Thus, comparison of radiation behavior of R6G in "photon boxes" and the conventionally used MSM with scattering distributed over all sample testify to the simultaneous appearance of RL and SRS in these samples. So these samples are a promising material for studying Raman spectra of dyes using SRS-RL phenomenon.

\section{Conclusions}

An alternative to the usually used types of dyed multiple scattering media for simultaneous initiation of stimulated Raman scattering and random lasing has been presented. This medium, which was conditionally denominated "photon box", is a homogeneous active medium (dyed polymer) surrounded with a diffusely reflecting cover. Owing to this design, dye molecules do not interact with scattering particles, which is important for unstable dyes.

The "photon box" operation was tested on samples dyed with rhodamine $6 \mathrm{G}$, since its behavior of coupled stimulated Raman scattering and random lasing are well studied in the media with uniform distribution of scattering particles.

Radiation spectra behavior of the tested samples depending on pumping intensity demonstrates the features of RL and SRS occurrence in "photon" boxes that are similar to those observed in vesicular films. The efficiency of SRS-RL phenomenon manifestation in these samples increases with the inner volume of the "photon box" approaching to the volume of excited region. The data presented show that "photon boxes" are an acceptable alternative to the usually used types of multiple scattering media for studying of stimulated Raman scattering of dyes.

\section{References}

1. D.S.Wiersma, Nature Phys., 4, 359 (2008).

2. V.P.Yashchuk, E.A.Tikhonov, O.A.Prygodiuk, Zh. Eksper. Teor. Fiz. Lett., 91, 174 (2010).

3. V.P.Yashchuk, E.A.Tikhonov, O.A.Prygodiuk, Mol. Cryst. Liq. Cryst., 535, 156 (2011).

4. V.P.Yashchuk, A.O.Komyshan, E.A.Tikhonov et al., Quant. Electron., 44, 921 (2014).

5. V.P.Yashchuk, E.A.Tikhonov, A.O.Bukatar et al., Quant. Electron., 41, 875 (2011).

6. Yashchuk V.P., Komyshan A.O., Smaliuk A.P. et al. Quant. Electron., 43, 1127 (2013).

7. G.van Soest, Phys. Rev. Lett., 86, 1522 (2001). 